\title{
POLSKA OBECNOŚĆ ARTYSTYCZNA WE FRANCJI - PRÓBA OCENY STANU BADAŃ
}

\author{
Ewa BOBROWSKA (Paryż)
}

, «Inna Europa» — w kierunku zmiany spojrzenia historiograficznego. Miejsce historii sztuki Europy Środkowej i Wschodniej we Francji"’. Taki tytuł nosiło sympozjum, jakie odbyło się w 2007 roku w Instytucie Narodowym Historii Sztuki w Paryżu, centralnej i najważniejszej instytucji w tej dziedzinie we Francji. Zorganizowane głównie przez ekipę pochodzenia rumuńskiego, z udziałem badaczy z różnych ośrodków uniwersyteckich we Francji, sympozjum miało wykazać, że historia sztuki, która rozwijała się przede wszystkim w krajach zachodnich, skupiała się na pewnych obszarach geograficznych i wybranych kwestiach, inne pozostawiając nietknięte. To ułomne, niekompletne spojrzenie przetrwało pomimo zmian, jakie zaszły w ostatnich latach w myśli historycznej oraz postępów metodologicznych. W ten sposób, według organizatorów, zarysowała się na mapie historii sztuki „Inna Europa”, nie brana bądź to w ogóle, bądź tylko punktowo pod uwagę jako rozszerzenie wpływów zachodnich. Innymi słowy, Europa nie-zachodnia widziana jest przez nią zasadniczo jako odbiorca różnego rodzaju modeli, pochodzących $\mathrm{z}$ „Europy wielkich trendów artystycznych”. Ukształtowaną w wyniku wydarzeń historycznych i geopolitycznych „Inną Europę”, powojenna żelazna kurtyna ukryła przed spojrzeniem Zachodu.

${ }^{1}$ Sympozjum „L'«Autre Europe» - Changer de regard historiographique. Quelle place pour l'histoire de l'art de l'Europe Centrale et de l'Est en France?', Institut national d'histoire de l'art, Paryż, 23.05.2007, materiały opublikowane w: Ligeia 2009 nr 93-96, s. 21-224. 
Celem sympozjum była analiza panującego we Francji zainteresowania badaniami nad sztuką Europy Środkowej i Wschodniej, określenie aktualnego stanu historiografii historii sztuki i refleksji nad możliwością decentralizacji jej zachodniej orientacji, a także próba oceny faktycznej obecności we Francji tematów odnoszących się do „Innej Europy”. Zgodnie z aktualnie panującymi trendami, program sympozjum obejmował kilka zasadniczych punktów, z których każdy omawiany był przez grupę dwóch, trzech dyskutantów.

Głównym wnioskiem, jaki nasunął się na zakończenie całodziennej debaty, było to, że dopiero upadek muru berlińskiego i będące jego politycznym skutkiem wejście niektórych krajów Europy Środkowej i Wschodniej do Unii Europejskiej otworzyły Francuzom oczy na dotyczącą je problematykę. Być może wniosek ten był słuszny w stosunku do niektórych krajów tego obszaru geopolitycznego. Moje osobiste ponaddwudziestoletnie doświadczenie w dziedzinie badań nad sztuką polską we Francji nie pozwalało mi się z nim pogodzić. Badania na tym polu rozpoczęły się bowiem dużo wcześniej. O tych wysiłkach nie wolno zapominać. W przypadku Polaków nie trzeba było czekać na zmiany polityczne, żeby je rozpocząć. Moje dyskusje z organizatorami sympozjum zaowocowały niniejszym artykułem². Pisząc go nie koncentrowałam się na całym rozległym polu badań jakim jest historia polskiej sztuki, ale zawęziłam je do twórczości artystów, którzy osiedlili się i działali we Francji. Twórcy ci powinni z definicji stanowić integralną część francuskiej sceny artystycznej i z tego chociażby powodu powinni byli stać się przedmiotem zainteresowania historyków sztuki działających w tym kraju.

Choć w ostatnim półwieczu Polska należała do „Innej Europy”, to jednak związki jej sztuki ze sztuką francuską datują się od dawna. Znacząca obecność artystów polskich we Francji od 1830 roku do dziś jest jedną ze szczególnych cech relacji kulturalnych polsko-francuskich. Trzeci rozbiór Polski i kolejne nieudane powstania niepodległościowe naznaczyły głęboko historię narodu polskiego. Zjawisko uchodźstwa, którego głównym celem było z jednej strony uniknięcie represji, z drugiej zaś zachowanie tożsamości i wartości narodowych i przygotowanie kolejnych akcji niepodległościowych, stało się zjawiskiem niemal codziennym. Zasadniczym kierunkiem polskiego exodusu politycznego do II wojny światowej była Francja. Pierwsza fala uchodźców, czyli Wielka Emigracja, przybyła tam w pierwszych latach monarchii lipcowej. W jej szeregach znalazło się około stu artystów. Aż do lat 90. XIX wieku artyści, którzy docierali nad Sekwanę, byli raczej emigrantami politycznymi, niż szukającymi artystycznych nowinek twórcami.

Pod koniec XIX wieku ruch pozytywistyczny wyznaczył kres akcji powstańczych. Naród polski był wyczerpany, zubożały i umęczony polityką wynarodowienia, prowadzoną przez zaborców. Paradoksalnie w tym właśnie okresie pojawiło się szczególne nasilenie talentów artystycznych. Brak sprzyjającej atmosfery dla ich rozwoju, a w szczególności brak ośrodków kształcenia artystycznego na poziomie wyższym nasuwał im pomysł wyjazdu zagranicę, najpierw do Monachium, a następnie do Paryża, który w tym czasie stał się światową stolicą sztuki. Napływ młodych polskich adeptów sztuki do nadsekwańskiej metropolii osiągnął szczyt na początku lat 10 . XX wieku, w okresie bezpośrednio poprzedzającym wybuch I wojny światowej. Po odzyskaniu niepodległości w 1918, wielu artystów powróciło do kuszącego obietnicami odro-

${ }^{2}$ E. Bobrowska, La présence des artistes polonais en France - état des lieux de la recherche, Ligeia $2009 \mathrm{nr}$ 93-96, s. 67-76. Prezentowana tu wersja jest rozszerzona. 
dzonego kraju. Nowa Polska prowadziła ożywioną działalność artystyczną z zagranicą. Celem jej było nie tylko zamanifestowanie swojej obecności kulturalnej, ale i politycznej na scenie międzynarodowej, jako pełnoprawnego członka światowej społeczności narodów. Na tej fali kolejne grupy młodych artystów przybywały do Paryża w okresie międzywojennym. Historia studentów wielkiego miłośnika sztuki francuskiej, Józefa Pankiewicza, i założonego przez nich Komitetu Paryskiego oraz paryskiej filii Akademii Sztuk Pięknych w Krakowie, są dobrze znane. Kryzys ekonomiczny lat 30. XX wieku, a wraz z nim nasilenie nacjonalizmu i ksenofobii we Francji skłoniły licznych twórców cudzoziemskich do jej opuszczenia. II wojna światowa i następujące po niej lata to kolejny okres migracji. Jesienią 1939 polski rząd i wojsko opuściły kraj i schroniły się początkowo we Francji. Wśród polskich żołnierzy byli również artyści. Niektórzy z nich udali się w dalszą drogę do Anglii, inni jednak pozostali we Francji. Po wojnie przejęcie władzy w Polsce przez komunistów skłoniło kolejnych jej obywateli do pozostania zagranicą. Po utrwaleniu się władzy komunistycznej w Polsce podróże na Zachód stały się rzadkością, opadła żelazna kurtyna, czego zasadniczo nie zmieniła krótkotrwała „odwilż” po śmierci Stalina. Kolejna wielka fala uchodźcza opuściła Polskę w okresie solidarnościowym na początku lat 80. Po upływie kolejnego dziesięciolecia, po zmianach politycznych początku lat 90., ruch emigracyjny nadal trwał. Jednak ówczesne wyjazdy, z przyczyn zasadniczo ekonomicznych, miały zupełnie inny charakter i pozbawione były elementu „,przymusowości”, który był cechą immanentną poprzednich fal emigracyjnych. Nie będziemy go więc brać pod uwagę w naszych rozważaniach.

Podsumowując, możemy więc wysunąć prawdopodobną hipotezę, że w okresie od 1830 roku do dziś ponad 1200 artystów polskich osiadło i działało we Francji, w tym około stu w okresie Wielkiej Emigracji ${ }^{3}$, kilkudziesięciu w ramach kolejnych fal uchodźstwa do Francji w XIX wieku ${ }^{4}$ i niemal 700 w latach $1890-1918^{5}$. Nie dysponujemy jak dotąd żadnym systematycznym studium na temat liczebności grupy artystów polskich, którzy przebywali dłużej we Francji w latach $1918-1980^{6}$, jednak analiza rozmaitych publikacji (artykułów itp.) sugeruje liczbę ok. 300. W naszych obliczeniach zatrzymujemy się na roku 1980, przed kolejną wielką falą uchodźców solidarnościowych, na których temat nie dysponujemy wystarczającymi informacjami.

Obserwując od kilkudziesięciu lat francuską scenę artystyczną zauważyć można, że pomimo tej znaczącej obecności fizycznej polskich twórców we Francji na przestrzeni ostatnich dwóch stuleci obecność polskiej sztuki w salach muzealnych, na rynku i w badaniach historyków sztuki wydaje się nieporównywalnie mała. Wystawy sztuki polskiej są rzadkie, mało dzieł polskich artystów wystawionych jest we francuskich muzeach, mało jest również publikacji w tej dziedzinie. Wydaje się więc rzeczą tym bardziej interesującą prześledzenie jej historiografii.

Los polskich emigrantów we Francji stał się obiektem zainteresowań badaczy, przede wszystkim polskich, od końca XIX wieku. Badania poświęcone były głównie emigracji politycznej, jej historii, a zwłaszcza jej inicjatywom niepodległościowym. Nieco później przyszła kolej na badania nad środowiskiem literackim i artystycznym.

\footnotetext{
${ }^{3}$ Por.: D. Wrotnowska, „Dictionnaire des artistes polonais de l'émigration 1830: peintres, graveurs, lithographes et dessinateurs”, praca dyplomowa, Paryż: École du Louvre, 1948.

${ }^{4}$ Tamże.

${ }^{5}$ Por.: E. Bobrowska-Jakubowski, „Le milieu des artistes polonais en France 1890-1918. Communautés et individualités”, rozprawa doktorska, Uniwersytet Paryż 1, 2001.

${ }^{6}$ Por. także: E. Bobrowska-Jakubowski, From Poland into the wide world. Polish artists in other countries' culture, Gazeta Antykwaryczna 2004 (special edition in English).
} 
Przed II wojną światową dystans nie był z pewnością wystarczający, by traktować te środowiska jako przedmiot poważnych badań historycznych. Artyści polscy działający we Francji w XIX i na początku XX wieku byli raczej obiektem zainteresowań dziennikarskich. Już wtedy pojawiła się świadomość konieczności podjęcia badań podstawowych. Przejawem jej było opracowanie pierwszych systematycznych bibliografii i katalogów. Przykładem może służyć katalog dzieł artystów polskich wystawionych na Salonach paryskich w XIX wieku ${ }^{7}$, zestawiony przez czynnego we Francji krytyka sztuki Antoniego Potockiego. Tom pracy Jana Lorentowicza La Pologne en France. Essai d'une bibliographie raisonnée ${ }^{8}$, poświęcony sztukom pięknym, pozostaje do dziś nieocenionym narzędziem dla każdego historyka sztuki zainteresowanego działalnością artystów polskich we Francji do lat 30. XX wieku. Dictionnaire des artistes polonais de l'émigration 1830: peintres, graveurs, lithographes et dessinateurs [Słownik artystów polskich Wielkiej Emigracji: malarzy, grafików, litografów i rysowników], zredagowany przez Denise Wrotnowską tuż przed II wojna światową i obroniony jako praca dyplomowa w Ecole du Louvre w Paryżu w $1948^{9}$, powinien był mieć potencjalnie wielki wpływ na rozwój badań w tej dziedzinie. Jednak moment historyczny jego powstania, najpierw cezura wojenna, potem zaś spadek zainteresowania Polską w powojennej Francji nie pozwolił na jego opublikowanie i spowodował, że jest on do dzisiaj znany jedynie garstce wtajemniczonych.

Po 1945 sytuacja polityczna w Polsce nie sprzyjała badaniom nad emigracją, w tym również nad artystami na uchodźstwie, podejrzanymi i politycznie niepoprawnymi, bo pozostającymi poza granicami kraju, ani też podróżom studyjnym na Zachód, w tym także do Francji. Władze komunistyczne były im niechętne z powodów politycznych i ekonomicznych. Od tego momentu pojawił się rozdział pomiędzy badaniami prowadzonymi przez badaczy w kraju, a tymi, którzy mieszkali zagranicą. Zjawisko to osiągnęło swego rodzaju apogeum w okresie emigracji solidarnościowej na początku lat $80 . \mathrm{XX}$ wieku ${ }^{10}$. Pomimo trudności spowodowanych zimną wojną naukowcy z kraju starali się kontynuować swe badania. Byli świadomi konieczności gromadzenia podstawowych danych, np. sporządzając inwentarze i spisy, których najlepszym przykładem jest spis artystów polskich biorących udział w salonach paryskich w XX wieku. Praca nad nim podjęta została pod koniec lat 50. ${ }^{11}$ Choć stanowiła ona wyjątkowej wartości przewodnik dla badaczy, zainteresowanych środowiskiem artystów polskich we Francji, jej zasięg był jednak ograniczony. Inwentarz, sporządzony w maszynopisie był niezwykle trudno dostępny przez ponad 40 lat od jego powstania. Wydania doczekał się dopiero w 2004 roku $^{12}$.

\footnotetext{
${ }^{7}$ A. Potocki, Kolonja Paryska i udziat Polaków na wystawach paryskich w XIX stuleciu, Sztuka (Paryż) 1904 (listopad-grudzień), s. 400-410.

${ }^{8}$ J. Lorentowicz, La Pologne en France. Essai d'une bibliographie raisonnée, 3 vol., Paris 1935, 1938, 1941.

${ }^{9}$ D. Wrotnowska, ,Dictionnaire des artistes polonais...”.

${ }^{10}$ Przełom w tym zakresie stanowiło sympozjum międzynarodowe „Jesteśmy” zorganizowane przez Instytut Sztuki PAN w Warszawie w dniach 3-5 września 1991 r., choć wydaje się, że do dziś wyniki badań prowadzonych przez specjalistów polskiego pochodzenia, działających zagranicą, napotykają na trudności w ich publikowaniu i akceptacji przez badaczy krajowych.

${ }^{11}$ H. Bartnicka, J. Szczepińska[-Tramer], „Katalog prac artystów polskich, wystawiających w Paryżu na: Salon des indépendants, Salon d'automne, Salon des Tuileries”, Warszawa 1960, mps.

${ }^{12}$ H. Bartnicka-Gorska, J. Szczepińska-Tramer, W poszukiwaniu światta, kształtu i barwy, Warszawa 2004; pozostaje jedynie żałować, że opracowanie nie zostało uaktualnione w sposób systematyczny.
} 
Postępy zaobserwować można było również w ramach badań monograficznych, prowadzonych m.in. przez Władysławę Jaworską i Helenę Blumównę. Doprowadziły one do wielkich odkryć i spektakularnych repatriacji dzieł artystów polskich czynnych we Francji: Olgi Boznańskiej (1865-1940) ${ }^{13}$, Władysława Ślewińskiego (1854-1918) ${ }^{14}$ i Tadeusza Makowskiego $(1882-1932)^{15}$. Potem przyszła kolej na inne monografie ${ }^{16}$. Podejście bardziej syntetyczne, a zwłaszcza analizy zjawisk bardziej kompleksowych, zbiorowych pojawiły się dopiero w latach 70 . i dotyczyły najpierw teatru ${ }^{17}$ i literatury $^{18}$, bądź szerzej życia kulturalnego. Sztuki plastyczne były tam tylko wzmiankowane. Prawdziwy zwrot w dziedzinie badań nad artystami emigracyjnymi dokonał się dopiero po okresie zmian politycznych w Polsce na początku lat 90. Przygotowywany był on już wcześniej, zwłaszcza przez działających na emigracji kolekcjonerów i marszandów, m.in. Wojciecha i Ewę Fibaków, Marka Mielniczuka czy Zbigniewa M. Legutkę. Sym-

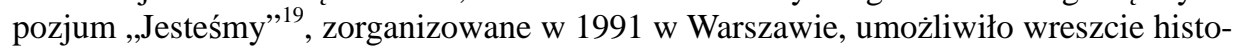
rykom polskiej sztuki odkrycie artystów często zapomnianych za czasów komunistycznych. Było ono również okazją do poznania i uznania prac na temat artystów emigracyjnych, a prowadzonych przez badaczy działających zagranicą. Materiały z tej sesji objęły zarówno prace o charakterze przekrojowym, podejmujące problemy historyczne i stylistyczne, jak i te o charakterze monograficznym, poświęcone twórcom czasami zupełnie nieznanym. Ta nowa tendencja badawcza, skoncentrowana na problemach emigracji, znalazła swe odbicie zarówno w publikacjach, jak i w wystawach dzieł artystów, tworzących zagranicą. Był to głęboki przełom w stosunku do polityki wystawienniczej prowadzonej za czasów komunistycznych, kiedy to na zasadzie syndromu „powrotu syna marnotrawnego” pokazywano na ogół prace artystów uznanych, których dzieła powróciły do Polski i trafiły do polskich muzeów. Zwrot ten był zresztą wyrazem ogólnej tendencji ,pojednania Kraju z emigracjąa, która wyraziła się zainteresowaniem historyków dziejami polskiej diaspory i jej instytucjami, m.in. archiwami, bibliotekami i muzeami. W rezultacie powstały w tym czasie liczne, mniej lub bardziej godne zaufania, słowniki, leksykony i encyklopedie Polonii.

${ }^{13}$ H. Blum, Olga Boznańska. Zarys życia i twórczości, Kraków 1964; taż, Olga Boznańska, Warszawa 1974 i in.

${ }^{14}$ W. Jaworska, W kręgu Gauguina. Malarze Szkoty Pont-Aven, Warszawa 1969; taż, Paul Gauguin et l'École de Pont-Aven, Neuchâtel [1971]; Wtadysław Ślewiński 1854-1918. [Wystawa monograficzna w Muzeum Narodowym w Warszawie], red. W. Jaworska, Warszawa 1983; taż, Władysław Ślewiński, Warszawa 1984; taż, Władystaw Ślewiński, Warszawa 1991 i późniejsze pozycje tej autorki.

${ }^{15}$ W. Jaworska, Tadeusz Makowski 1882-1932: malarstwo, rysunki, grafika. [Katalog] Muzeum Narodowe w Warszawie, Warszawa 1960; taż, Tadeusz Makowski: życie i twórczość, Wrocław 1964; taż, Tadeusz Makowski: polski malarz w Paryżu, Wrocław 1976 i in.

${ }^{16}$ A. Melbechowska-Luty, Teofil Kwiatkowski (1809-1891), Wrocław 1966; Konstanty Brandel: 1880-1970, [katalog wystawy] Muzeum Narodowe w Warszawie, Galeria Sztuki Współczesnej listopad-grudzień 1977, [oprac. I. Jakimowicz], Warszawa 1977; Konstanty Brandel 1880_ 1970: w stulecie urodzin, [wystawa] Muzeum Narodowe w Warszawie, 10 IV-18 V 1980 [katalog Dorota Folga-Januszewska], Warszawa 1980; Ł. Krzywka, Sztuk-mistrz polski Leon Kapliński (1826-1873), Wrocław 1994.

17 Z. Markiewicz, T. Sivert, Melpomena polska na paryskim bruku, Warszawa 1973; T. Sivert, Polacy w Paryżu. Z dziejów polskiego życia kulturalnego w Paryżu na przełomie XIX i XX wieku, Warszawa 1980.

${ }^{18}$ F. Ziejka, Paryż mtodopolski, Warszawa 1993.

${ }^{19}$ Między Polska a światem. Od średniowiecza po lata II wojny światowej, red. M. Morka, P. Paszkiewicz, Warszawa 1993. 
Otwarcie na polskie kolekcje prywatne, w szczególności powstałe zagranicą i gromadzące dzieła artystów emigracyjnych, często mniej znanych, nastąpiło przy okazji pokazu kolekcji Wojtka i Ewy Fibaków ${ }^{20}$. Kolekcja ta zawierała przede wszystkim prace artystów polskich związanych z Francją. Ta historyczna wystawa otworzyła drogę wielu wystawom zarówno zbiorowym, jak i przede wszystkim monograficznym, m.in. Mojżesza Kislinga ${ }^{21}$, Romana Kramsztyka ${ }^{22}$, Aliny Szapocznikow ${ }^{23}$, Simona Mondzaina, Jana Wacława Zawadowskiego (Zawado), Jana Hrynkowskiego ${ }^{24}$, Meli Muter $^{25}$, Gustawa Gwozdeckiego ${ }^{26}$, Eugeniusza Zaka ${ }^{27}$, od dawna oczekiwana retrospektywa Józefa Pankiewicza ${ }^{28}$, czy prezentacja prac Konstantego Brandla ${ }^{29}$. Powoli ruszyły również pokazy twórczości artystów okresu powojennego. Należała do nich wystawa twórczości Jerzego Kujawskiego ${ }^{30}$, czy też cykl wystaw nigdy wcześniej w Polsce nie wystawianego malarza Witolda Januszewskiego ${ }^{31}$. Trudno jest przecenić znaczenie każdej z tych prezentacji, które przywracają polskiej historii sztuki brakujące ogniwa i elementy, które spajają ją z historią sztuki światowej i pozwalają złagodzić szkodliwy wpływ kilkudziesięciu lat żelaznej kurtyny.

${ }^{20}$ Malarstwo polskie w kolekcji Ewy i Wojciecha Fibaków / Polish Painting in the Ewa and Wojtek Fibak Collection, Warszawa 1992.

${ }^{21}$ B. Brus-Malinowska, J. Malinowski, Kisling i jego przyjaciele: wystawa obrazów i rzeźb $z$ kolekcji Musée du Petit Palais w Genewie / Kisling and His Friends: Exhibition of Paintings and Sculptures From the Collection of the Musée du Petit Palais in Geneva, [red. E. Zdonkiewicz], Muzeum Narodowe w Warszawie, Warszawa 1996.

${ }^{22}$ Roman Kramsztyk 1885-1942, wystawa monograficzna [Galeria Sztuki Współczesnej Zachęta, Żydowski Instytut Historyczny], luty-marzec 1997, [R. Piątkowska, M. Tarnowska], Warszawa 1997.

${ }^{23}$ J. Gola, Katalog rzeźb Aliny Szapocznikow [Muzeum Narodowe w Krakowie], [współpraca M. Jeżewska i in.; red. nauk. Z. Gołubiew; red. B. Leszczyńska-Cyganik], Kraków-Łódź 2001.

${ }^{24}$ Simon Mondzain: Instytut Polski (Paryż), Galeria Sztuki Współczesnej Zachęta (Warszawa), Muzeum Śląskie (Katowice), Żydowski Instytut Historyczny (Warszawa) - 1999; Jan Wacław Zawadowski: Galeria Sztuki Współczesnej Zachęta (Warszawa), Muzeum Śląskie (Katowice), Żydowski Instytut Historyczny (Warszawa) - 2000; Jan Hrynkowski: Galeria Sztuki Współczesnej Zachęta (Warszawa), Muzeum Śląskie (Katowice), Żydowski Instytut Historyczny (Warszawa) - 2000

${ }^{25}$ Np.: Mela Muter: (Maria Melania Mutermilch 1876-1967): Kolekcja Bolestawa i Liny Nawrockich, grudzień 1994-luty 1995, Muzeum Narodowe w Warszawie, red. B. Brus-Malinowska, B. Nawrocki, Warszawa 1994; Mela Muter - portrety: z kolekcji Bolestawa i Liny Nawrockich, wystawa w Pałacu Radziejowickim, lipiec 2005, [red. W. Mielniczuk], Radziejowice 2005.

${ }^{26}$ A. Lipa, Gustaw Gwozdecki 1880-1935: wystawa monograficzna, Muzeum Narodowe w Poznaniu 23.02-13.04.2003, pod red. M. Gołąb, Poznań 2003.

${ }^{27}$ A. Tanikowski, Eugeniusz Zak, Sejny 2003.

${ }^{28}$ Józef Pankiewicz 1866-1940: życie i dzieło: artyście w 140. rocznice urodzin, Muzeum Narodowe w Warszawie, 9.01- 26.03.2006, red. E. Charazińska, Warszawa, 2006.

${ }^{29}$ E. Bobrowska-Jakubowska, M. A. Supruniuk, J. Krasnodębska, Katalog grafiki Konstantego Brandla ze zbiorów Archiwum Emigracji Biblioteki Uniwersyteckiej w Toruniu, Toruń 2005.

30 „Jerzy Kujawski «Maranatha»” — wystawa: Muzeum Narodowe w Poznaniu, 19.12.2005 - 5.02.2006; Narodowa Galeria Sztuki Zachęta, Warszawa, 22.04 - 28.05.2006. Kuratorem wystawy był Andrzej Turowski.

31 Geomancja w kolorach: Witold Januszewski (1915-1981): malarstwo, rysunek, Muzeum Wychodźstwa Polskiego, Łazienki Królewskie (Warszawa, 18.09 - 30.10.2007); Muzeum Uniwersyteckie (Toruń, 23.11.2007 - 22.01.2008), Muzeum Podlaskie, (Białystok 14.07 - 12.09.2008); kurator Ewa Bobrowska-Jakubowska; Harmonia wodnika: Witold Januszewski (1915-1981): malarstwo, rysunek / L'harmonie du verseau: Witold Januszewski (1915-1981): peinture, dessin, [katalog wystawy, Muzeum Narodowe w Kielcach, red. i tł. E. Bobrowska], Kielce 2010. 
Jeśli nawet badania poświęcone polskiej obecności artystycznej we Francji, prowadzone przez badaczy z Polski po upadku systemu komunistycznego są dalekie od opracowania całego pola badań obejmującego wspomnianych ponad 1200 twórców, postępy jakie zostały dokonane są niezaprzeczalne. Choć powszechna „moda” na emigrację minęła, to na szczęście pojedynczy badacze nadal się tą tematyką zajmują ${ }^{32}$. Pozostaje jedynie żałować, że ogromna większość polskich prac opublikowana jest jedynie w języku ojczystym ich autorów, czyli praktycznie niedostępna dla badaczy zagranicznych. Z kolei organizowane wystawy rzadko kiedy opuszczają granice Polski. Nie pozwala to na konfrontację rezultatów aktualnych polskich badań z szerokim kontekstem międzynarodowym.

Bariera językowa jest niewątpliwie jedną z przyczyn słabego rozwoju badań nad polską sztuką we Francji. Zasadnicze jednak wydają nam się przyczyny polityczne w czasie zimnej wojny. Zaledwie sztuce polskiej udało się, w okresie przed II wojną światową, znaleźć w kręgu zainteresowań Francuzów ${ }^{33}$, to już w okresie powojennym została ona z niego wyeliminowana z powodów politycznych. Sztuką polską we Francji zajmowali się jedynie lub w przytłaczającej większości badacze polskiego pochodzenia z pewnością z pobudek patriotycznych i tęsknoty za krajem. Jedną z nich była wspomniana wyżej Denise Wrotnowska. Publikowała ona zarówno po francusku, jak i po polsku, we francuskiej prasie specjalistycznej i w polskiej prasie emigracyjnej ${ }^{34}$, rezultaty swoich badań, dotyczących głównie twórców Wielkiej Emigracji. Moje niedawne przypomnienie jej „Słownika” przy okazji jednego z sympozjów ${ }^{35}$ skłoniło mnie do zrewidowania tematu. Stwierdziłam wówczas, że od czasu Wrotnowskiej właściwie nic nowego nie zostało zrobione w tej dziedzinie ani we Francji, ani w Polsce. Choć twórczość jej najwybitniejszych przedstawicieli, jak Piotr Michałowski i Teofil Kwiatkowski, doczekała się polskich monografii i wystaw, to jednak działalność polskich artystów Wielkiej Emigracji jako zjawisko pozostaje wciąż jeszcze swoistą terra incognita. Jest nadzieja, że młoda badaczka, Justyna Szemiel ${ }^{36}$, która w 2009 roku otworzyła przewód doktorski na Uni-

${ }^{32}$ Por.: A. Wierzbicka, Ecole de Paris. Pojęcie, środowisko, twórczość, Warszawa 2004; taż, Artyści polscy w Paryżu. Antologia tekstów 1900-1939, Warszawa 2008.

33 Jak o tym świadczą wybrane przykłady: Ch. Aronson, Art polonais moderne, Paris 1929; C. Osieczkowska, P. David, P. Guinard, A. J. Lauterbach, W. Tatarkiewicz, Art polonais, art français: études d'influences, avec une introd. par P. Moisy, Paris 1939.

${ }^{34}$ Lista wybranych publikacji Denise Wrotnowskiej na temat historii polskiej sztuki we Francji: Les Artistes polonais dans l'Ile Saint-Louis, Bulletin de la Société La Cité 1940 (styczeń/kwiecień); Les artistes polonais de l'émigration de 1830, Bulletin des Musées de France 1948 (październik); Les Artistes polonais de l'émigration de 1830, Direction des Musées de France. Position des thèses des élèves de l'Ecole du Louvre 1944-1951, Paris 1956; Gros et ses rapports avec les émigrés polonais en 1830, Bulletin de la Société de l'Histoire de l'Art français 1947-1948; Opiekun artystów na Emigracji, Syrena (Paryż) 30.07.1955; Pracownia L. Cognieta $i$ artyści emigracji, Syrena (Paryż) 29.03.1958; François Gérard et Léon Cogniet, protecteurs d'artistes polonais. Actes du XIXe Congrès International d'Histoire de l'Art, Paris, 1959, s. 455462; E. Fiszer, D. Wrotnowska, Catalogue des estampes de la Bibliothèque Polonaise, vol. 1: Portraits, vol. 2: Auteurs, Paris 1949, 1950.

${ }^{35}$ E. Bobrowska-Jakubowski, „Les peintres polonais en France sous la monarchie de Juillet” - międzynarodowe sympozjum interdyscyplinarne „Une ville, un destin. «Nantes: l'espoir du Bourbonnais Auguste Lacaussade»”, Musée départemental Dobrée de Nantes, Nantes 910.05.2008.

${ }^{36} \mathrm{~J}$. Szemiel, ,La production artistique des artistes polonais à Paris du début de la Grande Emigration de 1831 jusqu'à la fin du XIXe siècle”, rozprawa doktorska rozpoczęta w 2009, Uniwersytet Paryż 1 . 
wersytecie Paryż 1 na temat twórczości artystów polskich w Paryżu od czasów Wielkiej Emigracji do końca XIX wieku, wypełni tę poważną lukę.

Xavier Deryng, autor pracy doktorskiej na temat awangardy konstruktywistycznej w Polsce ${ }^{37}$, koncentruje swe badania na twórczości artystów polskich we Francji, w szczególności rzeźbiarza i malarza Bolesława Biegasa (1877-1954). Opublikował on m.in. monumentalny katalog przy okazji wystawy dzieł artysty zorganizowanej w Paryżu w $1992^{38}$. Niedawno poświęcił mu on dwie inne publikacje towarzyszące kolejnym wystawom ${ }^{39}$. Jego zainteresowania idą również w kierunku polskiego symboli$\mathrm{zmu}^{40}$, a także obecności polskich artystów $\mathrm{w}$ Bretanii ${ }^{41}$. Jest on również jednym z niezmiernie rzadkich wykładowców uniwersyteckich we Francji, którzy proponują swoim studentom tematy badawcze, związane $\mathrm{z}$ polską obecnością artystyczną we Francji.

Wydarzenia polityczne lat 80., a następnie wprowadzenie stanu wojennego w Polsce w 1981, pociągnęły za sobą emigrację, m.in. do Francji, znacznej liczby młodych Polaków. Wśród nich znaleźli się nie tylko liczni artyści, ale również historycy sztuki. Był to okres niezwykle dynamicznego rozwoju badań na temat polskiej sztuki, głównie w ramach prowadzonych prac doktorskich o charakterze przekrojowym. Małgorzata Dąbrowska-Szelągowska zajęła się rzeźbą polską na przełomie XIX i XX wie$\mathrm{ku}$, jej związkami ze sztuką francuską i próbami emancypacji ${ }^{42}$. Maria Diupero poświęciła swe badania związkom rzeźbiarza Émile'a Antoine'a Bourdelle'a z Polską ${ }^{43}$, przedstawiając artystę na tle polskiego środowiska artystycznego we Francji i odtworzyła przebieg jego pracy nad paryskim pomnikiem Mickiewicza. Zaprezentowała również twórczość polskich uczniów mistrza. Rozprawa doktorska Agnieszki Kluczewskiej-Wójcik przedstawiła za pośrednictwem wyjątkowej postaci kolekcjonera Feliksa Jasieńskiego ${ }^{44}$ całą złożoność związków pomiędzy kulturą polską i francuską na przełomie XIX i XX wieku. Rozprawa doktorska autorki niniejszych słów rzuciła światło na różnorodność przedsięwzięć zbiorowych artystów polskich we Francji

${ }^{37}$ X. Deryng, ,L'Avant-garde constructiviste en Pologne, 1922-1936: de Malevitch à Strzeminski: essai de confrontation de l'unisme avec le suprématisme, évolution de l'inobjectivité dans les années 20", rozprawa doktorska, Uniwersytet Paryż 1, 1981.

${ }^{38}$ Tenże, Boleslas Biegas: sculptures-peintures, Trianon de Bagatelle — Paris, 21.0531.08.1992, Paris 1992. Katalog ten zawiera wyczerpującą bibliografię autora na temat twórczości Biegasa.

39 Biegas et la musique, Bibliothèque Polonaise de Paris, 25 octobre - 2 décembre 2006, [red. X. Deryng, A. Czarnocka], Kraków 2006.

${ }^{40}$ Por. wystawy zaprezentowane w ramach Sezonu Polskiego we Francji; zob.: Le symbolisme polonais, éd. F. Ribemont, Paris 2004; Józef Mehoffer: un peintre symboliste polonais (1868-1946), éd. A. Zeńczak, X. Deryng, Paris 2004; A. Turowski, „Fin de temps! L'histoire n'est plus": l'art polonais de 20e siècle, Tulon 2004.

${ }^{41}$ X. Deryng, Artistes polonais en Bretagne 1890-1927, [w:] Artistes étrangers à Pont-Aven, Concarneau et autres lieux de Bretagne, [Rennes 1989].

${ }^{42}$ M. Dąbrowska-Szelągowska, „La sculpture polonaise 1887-1918. Entre les influences françaises et la quête d'un style national", rozprawa doktorska, Uniwersytet Paryż 10, 1997.

${ }^{43}$ M. Diupero, „Émile Antoine Bourdelle et la Pologne”, rozprawa doktorska, Uniwersytet Lyon 2, 1998, poprzedzona artykułem tejże: Le Monument à Mickiewicz de Bourdelle et son double commentaire par artiste, Histoire de l'art $1995 \mathrm{nr}$ 29/30.

44 A. Kluczewska-Wójcik, „Feliks Manggha Jasieński (1861-1929), collectionneur et animateur de la vie artistique en Pologne", rozprawa doktorska, Uniwersytet Paryż 1, 1998, poprzedzona artykułem tejże: Feliks Manggha-Jasieński, un collectionneur polonais au tournant du siècle, Histoire de l'art 1993 nr 21/22. 
w latach 1890-1918, podejmowanych głównie w obrębie stowarzyszeń ${ }^{45}$. Równocześnie dokonała ona analizy historii wybranych artystów, jak Bolesław Buyko, Olga Boznańska, Józef Pankiewicz, Jan Rubczak i inni. W pracy tej, będącej rozwinięciem badań podjętych w pracy magisterskiej, poświęconej Oldze Boznańskiej i jej związkom z Francją, zawarty został leksykon około 700 polskich twórców, czynnych we Francji w badanym okresie. Rozprawa doktorska Marty Chrzanowskiej-Foltzer przedstawia wyniki badań na temat polskiej obecności artystycznej na południu Francji w ostatnim stuleciu $^{46}$. Z kolei Wiesław Kilian pracuje nad tezą doktorską na temat grafików polskich we Francji ${ }^{47}$. Jego dysertacja poprzedzona była bardzo interesującymi, pionierskimi pracami na poziomie magisterskim, poświęconymi polskiemu udziałowi w Wystawie Międzynarodowej Sztuki i Techniki, jaka miała miejsce w Paryżu w 1937 roku, a następnie postaci krytyka polskiego pochodzenia Waldemara George'a (właściwie Jerzego Waldemara Jarocińskiego). Obecnie jednak spora część tych badaczy powróciła do Polski i znalazłszy się z dala od źródeł, zaniechała badań na temat twórców emigracyjnych. Niektórzy jednak publikują nadal zarówno we Francji, jak i w Polsce, odgrywając niezastąpioną rolę passeurs, czyli pośredników w kulturach obu tych krajów ${ }^{48}$. Często nie ograniczają się oni wyłącznie do publikacji uniwersyteckich, ale także organizują wystawy, dzięki którym popularyzują podjęte tematy prezentując je szerszej publiczności. W latach 1990 miała miejsce we Francji pewna liczba niewielkich, niskobudżetowych wystaw studyjnych ${ }^{49}$. Z kolei ambicją opracowanej przez Elżbietę Grabską i zaprezentowanej najpierw w Muzeum Bourdelle'a w Paryżu, a następnie w Muzeum Narodowym w Warszawie wystawy „Wokół Bourdelle’a. Paryż i artyści polscy $1900-1918$ "50 było nie tylko przedstawienie dzieł artystów, tworzących

${ }^{45}$ E. Bobrowska-Jakubowski, „Le milieu des artistes polonais...”; opublikowane w części jako: E. Bobrowska-Jakubowska, Artyści polscy we Francji 1890-1918. Wspólnoty $i$ indywidualności, Warszawa 2004.

46 M. Chrzanowska-Foltzer, „«Conversations provençales» - les peintres polonais en France méditerranéenne de 1909 à nos jours. Etude sur les influences et les échanges artistiques", rozprawa doktorska, Uniwersytet Paryż 1, 2006/2007.

${ }^{47}$ W. Kilian, „Les artistes graveurs polonais en France entre 1900 et 1939: les échanges internationaux et changement du paradigme artistique", rozprawa doktorska rozpoczęta w 2009, Uniwersytet Paryż 1.

${ }^{48}$ Lista wybranych publikacji autorki: Graver l'âme, graver l'art: Konstanty Brandel (1880_ 1970), Annales du Centre Scientifique de l'Académie Polonaise des Sciences 2006 vol. 9, s. 62-67 (z M. A. Supruniukiem); L'illustration au service de l'idée: Arthur Szyk et la tradition polonaise de l'illustration engagée, [w:] L'Illustration en Europe Centrale aux XIXe et XXe siècles. Un état de lieu, Paris 2006, s. 203-223 („Cultures d'Europe Centrale”, nr 6); Génie créateur face à Genius loci: les artistes polonais et leur promenades à travers la France au tournant du XXe siècle, [w:] „Genius loci face à la mondialisation” [colloque international], red. Z. Mitosek, A. CiesielskaRibard, Paris 2006 („Les nouveaux cahiers franco-polonais”, nr 6), s. 97-107.

49 „Dessins choisis de la collection de la Société Historique et Littéraire Polonaise”, Biblioteka Polska, Paryż 1988; „Olga Boznańska (1865-1940), peintures”, Muzeum Adama Mickiewicza, Biblioteka Polska, Paryż 1990; „Zawado. Wacław Zawadowski (1891-1982), peintures”, Biblioteka Polska, Paryż 1991; „Autour des associations artistiques polonaises en France: colloque - exposition - concert", Centrum Naukowe PAN, Paryż, maj - czerwiec 1996; „Gravure Passion 2006. Hommage à Konstanty Brandel (1880-1970) et Claude Breton (1928-2006)”, Fondation Taylor, Ateliers d'Art de la Ville de Saint-Maur, październik - listopad 2006.

${ }^{50}$ Autour de Bourdelle: Paris et les artistes polonais, 1900-1918, les musées de la Ville de Paris, Musée Bourdelle, 23 octobre 1996 - 19 janvier 1997, conception de l'exposition et du catalogue, E. Grabska, Paris 1996. 
polską kolonię artystyczną w Paryżu, ale przypomnienie tekstów krytycznych i archiwalnych z tamtego okresu. Wydany z tej okazji katalog jest wciąż jeszcze jedną z nielicznych publikacji na temat polskiej sztuki po francusku. Uzupełnieniem tej ekspozycji była przygotowana równolegle w Bibliotece Polskiej w Paryżu bardziej kameralna wystawa „Temps de paix — temps de guerre. Les artistes polonais à Paris 1900-1918”,51. Przedstawiła ona mniej znane aspekty tej samej problematyki za pośrednictwem, najczęściej nigdy wcześniej nie publikowanych, dokumentów archiwalnych i dzieł.

Sezon polski we Francji w 2004 stanowił znakomitą okazję do zaprezentowania polskiej sztuki szerszej publiczności francuskiej za pośrednictwem wystaw. Towarzyszyły im na ogół publikacje w języku francuskim, których do tej pory tak bardzo brakowało. Zorganizowane w większości przez czynniki oficjalne polskie i francuskie (ministerstwa kultury, muzea) objęły one szerokie spektrum historii polskiej sztuki ${ }^{52}$. Imprezy Sezonu Polskiego we Francji miały jednak na celu przede wszystkim zapoznanie publiczności francuskiej z polską kulturą wywodzącą się z kraju, a nie z emigracji. Jednym z nielicznych i bardzo cennych wyjątków była wystawa poświęcona polskim artystom w Bretanii zorganizowana wspólnie przez Muzeum Departamentalne w Quimper w Bretanii i Muzeum Narodowe w Warszawie ${ }^{53}$.

Jak już wspomnieliśmy wyżej, bariera językowa utrudnia badaczom francuskim podejmowanie tematów z dziedziny historii sztuki polskiej, nawet tej tworzonej na emigracji we Francji. W tym kontekście trzeba tym bardziej docenić prace Solange Milet nad katalogiem dzieł wszystkich (grafika) Louisa Marcoussisa (wł. Ludwika Markusa) ${ }^{54}$. Wspomnijmy tu jeszcze inne monografie artystów, których autorzy nie obawiali się stawić czoła trudnościom językowym. Należy do nich monografia poświęcona Henri Haydenowi ${ }^{55}$, katalog wystawy Jana Peskégo (1870-1949), zorganizowanej w $2002^{56}$, czy też wystawy twórczości Sonii Lewitskiej ${ }^{57}$. Trzeba zaznaczyć, że artyści, czynni we Francji, szczególnie w pierwszej połowie XX wieku, a wywodzący się z polskiego kręgu kulturowego, pojawiają się w opracowaniach i na wystawach, poświęconych międzynarodowemu środowisku artystycznemu Paryża tamtego okresu. Często jednak ich polskie korzenie ulegają zapomnieniu ${ }^{58}$. Dotyczy to takich artystów, jak Henryk Hayden, którego liczne wystawy miały miejsce we Francji od czasu jego śmierci w 1970 roku, Mojżesz Kisling, Louis Marcoussis, Simon Mondzain i inni. Podejście, uwzględniające dwukulturowość artysty, jakie zaprezentowano na wystawie

${ }^{51}$ Temps de paix - temps de guerre. Les artistes polonais à Paris 1900-1918, [red. E. Bobrowska-Jakubowski], Muzeum im. Bolesława Biegasa, Biblioteka Polska, Paris 1997.

${ }^{52} \mathrm{Z}$ braku miejsca nie możemy wymienić wszystkich ważniejszych wystaw i publikacji Sezonu Polskiego, ograniczymy się więc tylko do tych, które mają związek z polską obecnością artystyczną we Francji, np.: E. Charazinska, Witold Wojtkiewicz, une fable polonaise 1879-1909, Musée de Grenoble, Arles 2004; A. Turowski, Fin des temps! - l'histoire n'est plus, Toulon 2004; „Saison polonaise”, [numer specjalny] „Beaux-Arts magazine” [pod red. E. I. Nowak i E. Bobrowskiej-Jakubowskiej], Paris 2004.

${ }_{53}$ Peintres polonais en Bretagne 1890-1939, Plomelin 2004.

${ }_{54}^{54}$ S. Milet, Louis Marcoussis: catalogue raisonné de l'œuvre gravé, Copenhague 1991.

${ }^{55}$ S. Beckett, Ph. Chabert, Ch. Zagrodzki, Hayden, Paris 2005.

${ }^{56}$ Jean-Peské (1870-1949), Paris 2002.

${ }^{57}$ F. Roussier, Sonia Lewitska 1874-1937, Musée Mainssieux, Voiron, 28 octobre - 31 décembre 2006, Voiron 2007.

${ }^{58}$ Np.: Ch. Parisot, M. Restellini, Portraits et paysages chez Zborowski, Paris 1989; A. ReyPieferd, P. Ebéli, Montparnasse atelier du monde, ses artistes venus d'ailleurs. Hommage à Kisling, Marseille 1992; Années trente en Europe. Le temps menaçant 1929-1939, Paris 1997; L'Ecole de Paris 1904-1929, la part de l'Autre, Paris $2000 \mathrm{i}$ in. 
urządzonej w 2009 roku, w setną rocznicę urodzin André Blondela (Saszy Blondera) (1909-1949) w Museé Paul Valéry w Sète, należy jak na razie do rzadkości. Towarzysząca jej bogato ilustrowana publikacja w języku francuskim, zawierająca teksty autorów zarówno polskich, jak i francuskich ${ }^{59}$, zdaje się otwierać nowe perspektywy badań nad twórczością artystów polskiego pochodzenia we Francji.

Zarysowany powyżej stan badań nad polską obecnością we Francji jest niewątpliwie skrótowy i daleki od wyczerpania tematu ${ }^{60}$. Pozwala jednak na wyciągnięcie kilku ogólniejszych wniosków.

Pomimo zdecydowanej tendencji do globalizacji, jaka zarysowuje się w historii sztuki, wydaje nam się, że badania, w szczególności o charakterze podstawowym, pozostają wciąż jeszcze „narodowe”. Żeby badania „,polskie” mogły faktycznie rozwinąć się we Francji, uznanie ich wagi i znaczenia powinno przyjść z Polski. Niewątpliwie pół wieku komunizmu w Polsce zdecydowanie je opóźniło. Jeśli prace te są kontynuowane we Francji, to dlatego, że prowadzą je naukowcy polscy lub polskiego pochodzenia, którzy działając na styku dwóch kultur, operując obydwoma językami, odgrywają rolę pośredników. Trudno jest natomiast mówić o jakiejkolwiek strukturze, czy oficjalnej organizacji, czy instytucjonalizacji tych badań. Jeśli historia polskiej sztuki jest w ogóle wykładana na francuskich uniwersytetach, to dzieje się to dzięki osobistym zainteresowaniom i zaangażowaniu poszczególnych naukowców, takich jak Xavier Deryng czy Andrzej Turowski ${ }^{61}$. Zaznaczyć przy tym trzeba, że badacze zajmujący się problematyką polskiej kultury, pracujący na wydziałach języka polskiego i cywilizacji, wykazują mało zainteresowania dla sztuki. Być może obawiają się obcej im dziedziny? Zupełnie inaczej dzieje się jednak we Francji w dziedzinie historii sztuki amerykańskiej na przykład. Jest ona także stosunkowo nieznana i mało popularna wśród francuskich historyków sztuki, za to amerykaniści często się nią interesują. Francuscy historycy sztuki podejmują trudne wyzwanie, jakim jest kierowanie pracami młodych badaczy, najczęściej polskich bądź polskiego pochodzenia. Tych ostatnich przyciągają najczęściej dotąd nietknięte, powiedzieć by można „dziewicze” tematy i stosunkowa obfitość źródeł (głównie archiwalnych, ale też prasowych, a także dzieł sztuki). Badania te, jak już podkreślałam, wciąż jeszcze podstawowe, zmierzające do zgromadzenia korpusu artystów, dzieł i krytyków, odbywają się na peryferiach głównych zainteresowań francuskiej historii sztuki. Od mniej więcej dwudziestu lat zauważyć można w tej dziedzinie postęp dzięki badaniom nad obecnością artystów cudzoziemskich we Francji w wyniku prac prowadzonych nad internacjonalizacją roli kulturalnej Paryża pod koniec XIX i w pierwszej połowie XX wieku ${ }^{62}$.

Rola programów takich jak Sezon Polski we Francji jest z pewnością bardzo ważna, ale często ich realizacja praktyczna nie staje na wysokości zadania. Mnogość rozmaitych imprez pokazuje bogactwo prezentowanej kultury, ale mając charakter ulotny i punktowy nie gwarantuje w żaden sposób trwałego rozwoju badań i zainteresowań w tej dziedzinie. Oczywiście zmiany polityczne w Polsce i jej wejście do Unii Europejskiej spowoduje na dłuższą metę zmianę w tej dziedzinie. Polska, podobnie jak inne

${ }^{59}$ De Blonder à Blondel, Arles 2009, teksty: Jerzy Malinowski, Natasza Styrna, J.-J. Breton, Marie Boyé-Taillan, Pascal Bonafoux.

${ }^{60}$ Opracowania poświęcone historii i zawartości polskich kolekcji we Francji zasługują na osobny artykuł.

${ }^{61}$ Zob. też: A. Turowski, Existe-t-il un art de l'Europe de l'Est?, Paris 1986.

${ }^{62}$ Por. prace poświęcone obecności artystów amerykańskich, niemieckich, szwedzkich, japońskich, rosyjskich, czeskich, czy ukraińskich we Francji w XX wieku. 
kraje Europy Środkowej i Wschodniej, skorzysta z rozmaitych programów unijnych, których celem będzie lepsze wzajemne poznanie jej członków. Łatwość podróżowania i turystyki odegra $\mathrm{z}$ pewnością wielką rolę $\mathrm{w}$ otwarciu się badaczy zagranicznych na bogactwo i atrakcyjność sztuki zbyt długo pozostawionej na marginesie. Od kilku lat zaobserwować można tendencje do podejmowania ,polskich” tematów, nie mających już nic wspólnego z twórczością emigracyjną w przypadku prac doktorskich z historii sztuki, prowadzonych na francuskich uniwersytetach ${ }^{63}$. Przeciwnie, w zdecydowanej większości podjęte tematy dotyczą sztuki współczesnej, które w pewnym sensie spychają w niepamięć ciążące na ostatnim półwieczu podziały polityczne i kulturalne.

Jestem świadoma, że ten skrótowy przegląd tematu, jaki niniejszym proponuję, jest daleki od jego problematyzacji. Wydaje mi się jednak, że warto zwrócić uwagę badaczy, że polska obecność artystyczna we Francji jest przedmiotem ciągłych, choć dyskretnych badań od ponad stu lat i że mimo to jest jeszcze dużo do zrobienia. Podkreślić raz jeszcze należy, korzystną sytuację polityczną, w jakiej znalazła się Polska jako pełnoprawny członek Unii Europejskiej. To do niej przede wszystkim należy wzbudzanie zainteresowania cudzoziemców jej sztuką i inicjowanie programów wystawienniczych, popularyzatorskich i badawczych. Wkład głównych „aktorów” rynku sztuki, czyli marszandów i kolekcjonerów, byłby tu również nie do przecenienia.

${ }^{63}$ Por. rozprawy doktorskie obronione: K. Hałas, „De l'Etat de guerre à la nouvelle démocratie: cheminement de l'art indépendant en Pologne de 1981 à la fin des années 1990", Uniwersytet Paryż 1, 2009; E. I. Nowak, „L'art face à la politique: l'art polonais dans le contexte sociopolitique dans les années 1945-1970 et après 1989”, Uniwersytet Paryż 1, 2009. Rozprawy doktorskie w toku: J. Szerer, „La représentation du paysan dans la peinture polonaise durant la seconde moitié du XIXe siècle et le début du XXe. Influences et analogies venant de la peinture européene”, Uniwersytet Paryż 4, rozpoczęta w 2002; A. Migdał, „Regina Ceoli. Les images de la Vierge et le culte des reliques. Tableaux-reliquaires polonais à l'époque médievale”, Uniwersytet Lyon 2, rozpoczęta w 2003; K. Cytlak, „L'espace sensible. Les représentations d'architectures intérieures dans l'art contemporain en Europe de l'Est. L'exemple polonais polonais”, Uniwersytet Paryż 1, rozpoczęta w 2005; F. Le Gall, „La scène artistique polonaise depuis 1989", Uniwersytet Rennes 2, rozpoczęta w 2005. 